\author{
ANNA PŁOŃSKA \\ ORCID: 0000-0003-1191-7407 \\ Uniwersytet Wrocławski \\ Zakład Prawa o Wykroczeniach, Karnego Skarbowego i Gospodarczego
}

\title{
KONCEPCJA ZAMIANY ODPOWIEDZIALNOŚCI ZA WYKROCZENIA W ODPOWIEDZIALNOŚĆ ADMINISTRACYJNĄ
}

\begin{abstract}
Abstrakt: Niniejszy artykuł przedstawia zagadnienia związane z leżącą na styku prawa o wykroczeniach i prawa administracyjnego koncepcją konwersji, będącej zabiegiem ustawodawcy mającym na celu przekształcanie wykroczeń w naruszenia prawa polegające na niedopełnieniu obowiązku albo naruszeniu zakazu ciążącego na osobie fizycznej, osobie prawnej albo jednostce organizacyjnej niemającej osobowości prawnej (tak zwane delikty administracyjne). Celem artykułu jest zwrócenie uwagi na istotne problemy związane z zamianą odpowiedzialności za wykroczenia w odpowiedzialność administracyjną oraz podkreślenie potrzeby wprowadzenia odrębnej regulacji prawnej dotyczącej zasad odpowiedzialności za delikty administracyjne.
\end{abstract}

Słowa kluczowe: wykroczenie, prawo wykroczeń, delikt administracyjny, konwersja, administracyjne kary pieniężne

„Odpowiedzialność” jest jednym z najczęściej używanych pojęć w języku zarówno prawnym, jak i prawniczym. „Odpowiedzialność prawna” natomiast ujmowana jest jako abstrakcyjna konstrukcja myślowa, wiążąca skutki prawne z określonymi sytuacjami naruszenia obowiązującej normy prawnej ${ }^{1}$. Zjawisko zamiany odpowiedzialności za wykroczenia w odpowiedzialność administracyjną nie jest nowością w polskim ustawodawstwie. Za pierwszy akt prawny wprowadzający odpowiedzialność za delikt administracyjny uważa się dekret z 1953 roku o użytkowaniu energii elektrycznej i cieplnej². Tendencja do zamiany reżimu odpowiedzialności karnej na odpowiedzialność administracyjną występuje nie tylko w Polsce, lecz także w pozostałych krajach europejskich. W rekomendacji Komi-

${ }^{1}$ M. Bogucka, Odpowiedzialność karna a odpowiedzialność administracyjna w kontekście kary pieniężnej w prawie farmaceutycznym, KKRS 2018, nr 2, s. 72.

2 Dz.U. z 1953 r. Nr 9, poz. 26; W. Radecki, [w:] Reforma prawa wykroczeń, t. 1, red. P. Daniluk, Warszawa 2019, s. 30. 
tetu Ministrów Rady Europy nr R (91) z 13 lutego 1991 roku w sprawie sankcji administracyjnych wskazano pozytywne aspekty omawianej koncepcji, odnosząc się do rozszerzania kompetencji sanacyjnych jako rezultatu wzrostu państwa administracyjnego oraz widocznej tendencji w kierunku dekryminalizacji. Jej uzasadnieniem zaś są między innymi: szybkość i uproszczony tryb stosowania sankcji administracyjnych, odciążenie sędziów, uwolnienie się spod rygorów właściwych prawu karnemu oraz wpływ prawa wspólnotowego, preferującego stosowanie sankcji niepenalnych ${ }^{3}$.

Odpowiedzialność za delikty administracyjne jest jednym z fundamentalnych problemów współczesnego prawa represyjnego ${ }^{4}$. Już od lat dziewięćdziesiątych $\mathrm{XX}$ wieku ustawodawstwo z zakresu prawa wykroczeń i prawa karnego ewoluowało ku realizacji zasady rzetelnego procesu, zapewniającej należyte gwarancje ochrony jednostki przed bezzasadnym ukaraniem. Jednocześnie ciągle rozszerzano różne, często zakamuflowane, formy karania w postaci między innymi kar pieniężnych wymierzanych $\mathrm{w}$ trybie administracyjnym, cechujących się wysokim stopniem dolegliwości ekonomicznej i słabo rozwiniętymi gwarancjami ochrony przez bezzasadnym ukaraniem ${ }^{5}$. D. Szumiło-Kulczycka wprowadziła, w ramach ogólnie rozumianej odpowiedzialności administracyjnej, pojmowanej jako „regulowana prawnie możliwość uruchomienia wobec określonego podmiotu z powodu jego działalności środków prawnych realizowanych w administracyjnych formach i procedurze", stanowiące metodologiczne narzędzie pojęcie prawa administracyjno-karnego, określane jako „ogół regulacji prawnych obejmujących ustanowienie i dochodzenie odpowiedzialności z tytułu naruszenia norm prawa administracyjnego obwarowanych sankcją w postaci kary pieniężnej, opłaty sankcyjnej, opłaty podwyższonej lub podobnej finansowej sankcji realizowanej w administracyjnym postępowaniu i przed administracyjnym organem"'. R. Zawłocki mówi o administracyjnym prawie karania, które w ostatnich czasach rozwinęło się tak, że może być zestawiane z obowiązującym prawem karnym sensu largo. Powoduje to w konsekwencji istotny problem granic i treści owej administracyjnej penalizacji w kontekście naruszenia porządku konstytucyjnego państwa prawnego ${ }^{7}$. R.A. Stefański z kolei zwraca uwagę, że nazywanie odpowiedzialności za delikty administracyjne, sankcjonowane administracyjnymi karami pieniężnymi, odpowiedzialnością administracyjną jest błędne ze względu na jej zakres przedmiotowy, który jest szerszy i obejmuje wszelkie formy władztwa administracyjnego. Autor ten wskazuje, że z uwagi na to, że jest to odpowiedzialność za naruszenia

3 I. Sepioło-Jankowska, Odpowiedzialność administracyjna jako odpowiedzialność alternatywna dla deliktów finansowych, Prok. i Pr. 2020, nr 1, s. 82.

${ }^{4}$ W. Radecki, [w:] M. Bojarski, W. Radecki, Kodeks wykroczeń. Komentarz, Warszawa 2019, s. 40 .

5 D. Szumiło-Kulczycka, Prawo administracyjno-karne, Kraków 2004, s. 13.

${ }^{6}$ Ibidem, s. 25, 29.

7 Zob. szerzej R. Zawłocki, Pojęcie i istota deliktu administracyjnego, MOP 2018, nr 1, s. 13. 
norm prawa administracyjnego, właściwe jest określenie jej jako odpowiedzialności administracyjnej karnej, nietożsamej z wywodzącą się z dawnego porządku prawnego, obejmującą naruszenia godzące w porządek, spokój i bezpieczeństwo publiczne i realizowaną przez organy administracyjne odpowiedzialnością karno-administracyjną ${ }^{8}$.

Przejmowanie wykroczeń przez regulacje dotyczące deliktów administracyjnych jest szczególnie widoczne na gruncie pozakodeksowego materialnego prawa wykroczeń. W ciągu lat zjawisko to dało się zauważyć między innymi w prawie atomowym, prawie energetycznym, prawie morskim, ustawie z dnia 27 kwietnia 2001 roku o odpadach ${ }^{9}$ zastąpionej ustawą z dnia 14 grudnia 2012 roku o odpadach $^{10}$, w ustawie z dnia 20 stycznia 2005 roku o recyklingu pojazdów wycofanych z eksploatacji ${ }^{11}$, ustawie $\mathrm{z}$ dnia 21 stycznia 2005 roku o doświadczeniach na zwierzętach ${ }^{12}$ zastąpionej ustawą z dnia 15 stycznia 2015 roku o ochronie zwierząt wykorzystywanych do celów naukowych lub edukacyjnych ${ }^{13}$, w ustawie z dnia 20 kwietnia 2004 roku o substancjach zubożających warstwę ozonową ${ }^{14}$ zastąpionej ustawą z dnia 15 maja 2015 roku o substancjach zubożających warstwę ozonową oraz o niektórych fluorowanych gazach cieplarnianych ${ }^{15}$ czy też w ustawie z dnia 23 lipca 2003 roku o ochronie zabytków i opiece nad zabytkami ${ }^{16}$ znowelizowanej na mocy ustawy z dnia 22 lipca 2017 roku $^{17}$. Ramy niniejszego opracowania nie pozwalają na szczegółowe omówienie wszystkich przypadków konwersji wykroczeń w delikty administracyjne. Nie jest to jednak zjawisko występujące sporadycznie.

Jako że koncepcja zamiany odpowiedzialności karnej, w tym także odpowiedzialności za wykroczenia, w odpowiedzialność administracyjną staje się podstawą zmiany przestępstw i wykroczeń w tak zwane delikty administracyjne, istotne znaczenie mają jej aksjologiczne przesłanki. W tle każdej bowiem instytucji prawnej, przy założeniu racjonalnego prawodawcy, leży zawsze jakiś zespół wartości ${ }^{18}$. W zespole wartości właściwych prawu administracyjnemu wskazuje się: powszechne wartości uniwersalne wspólne wszystkim gałęziom prawa (dobro człowieka, moralność sprawiedliwość), wartości niepochodzące z zewnątrz, lecz

8 R.A. Stefański, Odpowiedzialność administracyjna czy karna sensu largo?, [w:] Węłowe problemy prawa wykroczeń - czy potrzebna jest reforma?, red. M. Kolendowska-Matejczuk, V. Vacher, Warszawa 2016, s. 11.

9 Dz.U. z 2001 r. Nr 62, poz. 628.

10 Tekst jedn. Dz. U. z 2019 r. poz. 701 ze zm.

11 Dz.U. z 2005 r. Nr 25, poz. 202; oraz tekst jedn. Dz.U. z 2019 r. poz. 1610.

12 Dz.U. z 2005 r. Nr 22 poz. 289 ze zm.

13 Dz.U. z 2015 r. poz. 1207.

14 Dz.U. z 2004 r. poz. 436.

15 Dz.U. z 2017 r. poz. 1951.

16 Dz.U. z 2003 r. Nr 162, poz. 1568

17 Dz.U. z 2017 r. poz. 1595. Zob. W. Radecki, [w:] M. Bojarski, W. Radecki, op. cit., s. 116 n.

18 J. Zimmermann, Aksjomaty prawa administracyjnego, Warszawa 2013, s. 74. 
tworzone przez system prawny oparty na Konstytucji (publiczne prawo podmiotowe, racjonalność i klarowność tworzonego prawa, jawność procesu), a także interes publiczny oraz klasyczne wartości ujęte przedmiotowo (na przykład bezpieczeństwo ${ }^{19}$. M. Stec dodaje jeszcze jedną wartość — szybkość działania administracji ${ }^{20}$. Ustawodawca, wprowadzając do kodeksu postępowania administracyjnego dział IVa, na mocy nowelizacji z 2017 roku $^{21}$ stworzył niejako namiastkę części ogólnej przepisów o odpowiedzialności za delikty administracyjne ${ }^{22}$. Należy zwrócić uwagę, że powyższe zmiany przyniosły najdalej idącą reformę k.p.a. od 1980 roku, a uregulowanie zagadnienia administracyjnych kar pieniężnych było istotne głównie z punktu widzenia praktyki ${ }^{23}$. Już w uzasadnieniu do projektu nowelizacji zaznaczano, że przedmiotowa regulacja nawiązuje do cech instytucji charakterystycznych dla prawa karnego, mimo braku konieczności wskazywania przez organ winy sprawcy w związku z nałożeniem na dany podmiot administracyjnej kary pieniężnej ${ }^{24}$. Samo jednak pojęcie deliktu administracyjnego nie zostało zdefiniowane ustawowo.

Artykuł 189b k.p.a. definiuje administracyjną karę pieniężną jako

określoną w ustawie sankcję o charakterze pieniężnym, nakładaną przez organ administracji publicznej, w drodze decyzji, w następstwie naruszenia prawa polegającego na niedopełnieniu obowiązku albo naruszeniu zakazu ciążącego na osobie fizycznej, osobie prawnej albo jednostce organizacyjnej nieposiadającej osobowości prawnej.

Administracyjne kary pieniężne są sankcjami administracyjnymi określanymi jako instrument służący respektowaniu nakazów i zakazów stanowionych przepisami prawa administracyjnego. Jak wskazuje M. Wincenciak, w odróżnieniu od celów prawa karnego wymierzenie sankcji administracyjnej nie powinno być utożsamiane $\mathrm{z}$ odwetem za dopuszczenie się działania zabronionego przez prawo, ale jako skutek zaistnienia stanu niezgodnego z prawem, który wymaga reakcji organu administracji publicznej polegającej na przymuszeniu do przywrócenia stanu

19 Zob. szerzej M. Stec, Założenia aksjologiczne rządowego procesu legislacyjnego i ich realizacja, [w:] Aksjologia prawa administracyjnego, t. 1, red. J. Zimmermann, Warszawa 2017, s. 348-349.

20 Ibidem, s. 359.

${ }^{21}$ Ustawa z dnia 7 kwietnia 2017 roku o zmianie ustawy - Kodeks postępowania administracyjnego oraz niektórych innych ustaw (Dz.U. z 2017 r. poz. 935).

22 W. Radecki, Delikty administracyjne w prawie czeskim po reformie prawa wykroczeń z polskiej perspektywy, Prok. i Pr. 2020, nr 1, s. 20.

23 E. Żołnierczyk, Sankcja administracyjna - rozważania na temat administracyjnych kar pieniężnych wprowadzonych nowelizacją Kodeksu postępowania administracyjnego z 2017 r., [w:] Polski system ochrony praw człowieka 70 lat po proklamowaniu Powszechnej Deklaracji Praw Człowieka. Osiagnięcia - bariery - nowe wyzwania i rozwiązania, red. J. Jaskiernia, K. Spryszak, Torun 2019, s. 464.

${ }^{24}$ M. Bogucka, op. cit., s. 75. 
zgodności z prawem ${ }^{25}$. Ustanowienie expressis verbis, że administracyjna kara pieniężna jest sankcją, pozwala odróżnić ją od opłat administracyjnych. Naruszenie obowiązującego porządku prawnego może być obwarowane różnymi rodzajami sankcji, niemniej jednak sankcje przyjęte na gruncie regulacji materialnego prawa administracyjnego mogą być nakierowane na różne następstwa prawne wobec osób dopuszczających się naruszenia przepisów prawa. Administracyjna kara pieniężna jest nakładana w następstwie naruszenia prawa polegającego na niedopełnieniu obowiązku albo naruszeniu zakazu ustanowionego przepisami prawa. Jej zakres podmiotowy wskazuje, że może być ona nakładana na osoby fizyczne, osoby prawne, jak też jednostki niemające osobowości prawnej, co odpowiada zakresowi odpowiedzialności administracyjnej wskazanej w art. 29 k.p.a. ${ }^{26}$ Istnienie administracyjnych kar pieniężnych uzasadniane jest zarówno możliwością zastosowania ich w różnorakich celach i względem wszystkich podmiotów, jak i ze względu na zaspokojenie potrzeb finansowych państwa. Niemniej w doktrynie nie ma jednolitego stanowiska co do charakteru prawnego administracyjnych kar pieniężnych ${ }^{27}$. Postulat zaś opracowania specjalnej ustawy określającej zasady odpowiedzialności za delikty administracyjne coraz częściej i dosadniej wybrzmiewa $\mathrm{w}$ doktrynie ${ }^{28}$. D. Danecka proponuje de lege ferenda stworzenie odrębnego aktu normatywnego w postaci kodeksu karnego administracyjnego (kodeksu administracyjnych kar pieniężnych), przykładowo na wzór kodeksu karnego skarbowego, zawierającego materialną część ogólną, materialną część szczególną oraz część procesową ${ }^{29}$.

Zakres spraw, w których organy administracji orzekają w drodze decyzji administracyjne kary pieniężne, rozszerza się. W praktyce w coraz większym stopniu wprowadza się odpowiedzialność administracyjną, zastępując dotychczas istniejącą odpowiedzialnością z tytułu wykroczeń. Jak wskazuje M. Rogalski, istotne znaczenie ma ustalenie dóbr, które powinny być chronione przepisami prawa administracyjnego, oraz dóbr, które powinny być chronione na gruncie innych dziedzin prawa. Kwestia kwalifikacji dóbr podlegających ochronie w danej dziedzinie prawa powinna się opierać na zagadnieniach zarówno materialnoprawnych, jak i proceduralnych. Istnieje bowiem zasadnicza różnica między przepisami materialnego i procesowego prawa administracyjnego oraz materialnego i procesowego prawa

${ }_{25}$ M. Wincenciak, Aksjologia sankcji administracyjnej a przedawnienie jej wymierzania lub wykonania, [w:] Aksjologia prawa..., s. 1182-1183.

26 B. Adamiak, [w:] B. Adamiak, J. Borkowski, Kodeks postepowania administracyjnego. Komentarz, Warszawa 2019, s. 1025.

27 D. Danecka, Konwersja odpowiedzialności karnej w administracyjna w prawie polskim, Warszawa 2018, s. 340.

28 W. Radecki, [w:] M. Bojarski, W. Radecki, op. cit., s. 39-40; zob. też R. Zawłocki, op. cit., s. 24; D. Danecka, op. cit., s. 347.

29 D. Danecka, op. cit., s. 347. 
wykroczeń, które przyznają znacznie szerszy zakresu praw i możliwości obrony ${ }^{30}$. W wypadku zjawiska konwersji mamy do czynienia z sytuacją, gdy zachowanie, dotychczas typizowane jako wykroczenie, zostaje przekształcone w tak zwany delikt administracyjny. Dobro prawne zaś, dotychczas chronione na gruncie prawa wykroczeń, staje się przedmiotem ochrony prawa administracyjnego. U podstaw koncepcji zmiany odpowiedzialności za wykroczenia w odpowiedzialność administracyjną ustawodawca z pewnością kierował się rozbudowaniem katalogu podmiotów podlegających odpowiedzialności, gdyż administracyjna kara pieniężna może być nałożona nie tylko na osobę fizyczną, lecz także na osobę prawną albo jednostkę organizacyjną niemającą osobowości prawnej. Nadto postępowanie administracyjne jest procedurą zdecydowanie szybszą niż postępowanie w sprawach o wykroczenia. Koncepcja przekształcenia przez ustawodawcę czynu typizowanego jako wykroczenie lub przestępstwo w czyn zagrożony administracyjną karą pieniężną, zwana konwersją, polega głównie na uchyleniu przepisu typizującego dane wykroczenie lub przestępstwo, a następnie ujęciu go w unormowaniach tej samej lub innej ustawy, z jednoczesną zmianą dotychczasowego zagrożenia karą lub karami na administracyjną karę pieniężną. Konwersja może również polegać na tym, że ustawodawca nie uchyla przepisu stanowiącego o odpowiedzialności za wykroczenie lub odpowiedzialności karnej, ale „obok” niego tworzy nowy przepis typizujący ten sam czyn jako naruszenie prawa zagrożone administracyjną karą pieniężną. W doktrynie wyróżnia się konwersję pełną, niepełną, zewnętrzną i wewnętrzną w konfiguracjach: konwersji pełnej wewnętrznej, konwersji pełnej zewnętrznej, jak również konwersji niepełnej wewnętrznej oraz konwersji niepełnej zewnętrznej ${ }^{31}$.

Konwersja wykroczeń w delikty administracyjne w zdecydowanej większości przypadków wiąże się także ze znacznym zwiększeniem wysokości przewidywanej kary. Trudno znaleźć aksjologiczne uzasadnienie tego zjawiska z punktu widzenia znacznego zwiększenia ekonomicznej dolegliwości administracyjnych kar pieniężnych. Nie oznacza to jednak całkowitej negacji konwersji, lecz jedynie wielokrotnie postulowaną $\mathrm{w}$ doktrynie potrzebę wprowadzenia określonych $z_{\text {zmian }}{ }^{32}$. Ponadto zmiana charakteru odpowiedzialności z wykroczeniowej na administracyjną znacznie osłabia pozycję procesową podmiotu karanego. Ochrona określonych dóbr przez zmianę dziedziny prawa pozbawia bowiem karany podmiot jego praw w zakresie gwarancji procesowych, w tym przede wszystkim prawa do obrony czy też poszanowania zasady ne bis in idem. Tymczasem wśród przesłanek nakładania administracyjnej kary pieniężnej art. 189d k.p.a. wskazuje: wagę i okoliczności naruszenia prawa, a w szczególności potrzebę ochrony życia lub zdrowia, ochrony mienia w znacznych rozmiarach lub ochrony ważnego

${ }^{30}$ M. Rogalski, Aksjologia administracyjnych kar pieniężnych, [w:] Aksjologia prawa..., s. 1201.

31 D. Danecka, op. cit., 339.

32 M. Rogalski, [w:] Aksjologia prawa..., s. 1202. 
interesu publicznego albo wyjątkowo ważnego interesu strony oraz czas trwania tego naruszenia; częstotliwość niedopełniania w przeszłości obowiązku albo naruszania zakazu tego samego rodzaju; uprzednie ukaranie za to samo zachowanie za przestępstwo, przestępstwo skarbowe, wykroczenie lub wykroczenie skarbowe; stopień przyczynienia się do powstania naruszenia prawa; podjęte dobrowolnie działania w celu uniknięcia skutków naruszenia prawa; wysokość osiągniętej korzyści lub uniknionej straty; jak i warunki osobiste, gdy administracyjna kara pieniężna jest nakładana na osobę fizyczną. B. Adamiak zauważa, że obowiązek ustalenia przez organ administracji stanu faktycznego z uwzględnieniem okoliczności naruszenia prawa wskazuje na odchodzenie od reguły obiektywnej odpowiedzialności w kierunku regulacji przyjętej przy stosowaniu sankcji karnych ${ }^{33}$. Trzeba jednak pamiętać, że przesłanki wymierzania administracyjnych kar pieniężnych zawarte są również w ustawach szczególnych, a intencją ustawodawcy było założenie, że dyrektywy ujęte w art. 189d k.p.a. stosowane będą, gdy ustawy szczególne nie zawierają regulacji w tej materii bądź są one niewystarczające ${ }^{34}$. Słusznie wskazuje W. Radecki, że wprowadzenie do k.p.a. działu IVa nie rozwiązało problemu właściwej legislacji dotyczącej odpowiedzialności za delikty administracyjne. Autor ten podkreśla głównie powodujące wrażenie przesunięcia kategorialnego w wyniku wprowadzenia regulacji o charakterze materialnym do ustawy stricte procesowej; przyznanie pierwszeństwa regulacjom z ustaw szczególnych na podstawie art. 189f pkt 2 k.p.a. oraz przełamanie zasady ne bis in idem w art. 189f $\S 1$ pkt 2 k.p.a., na podstawie którego organ administracji publicznej, w drodze decyzji, odstępuje od nałożenia administracyjnej kary pieniężnej i ogranicza się do pouczenia, jeżeli za to samo zachowanie uprzednio nałożona została administracyjna kara pieniężna przez inny uprawniony organ administracji publicznej lub strona została prawomocnie ukarana za wykroczenie lub wykroczenie skarbowe, lub prawomocnie skazana za przestępstwo lub przestępstwo skarbowe, przy założeniu że uprzednia kara spełnia cele, dla których miałaby być nałożona administracyjna kara pieniężna. Ocena zatem, czy właściwe cele zostaną spełnione, czy też nie, pozostaje w gestii organu właściwego do nałożenia administracyjnej kary pieniężnej. Konsekwencją ustalenia odmiennych celów będzie jawnym pogwałceniem zasady ne bis in idem ${ }^{35}$.

Sama koncepcja zamiany odpowiedzialności wykroczeniowej na administracyjną ma wiele zalet, jednak poważne wątpliwości budzi to, z jaką łatwością przychodzi ustawodawcy legislacyjny zabieg zmiany charakteru odpowiedzialności nie tylko za wykroczenia, lecz także odpowiedzialności karnej w odpowiedzialność administracyjną bez kompleksowej regulacji za delikty administracyjne o charakterze materialnoprawnym. Jednoznaczne oddzielenie odpowiedzialności

\footnotetext{
33 B. Adamiak, op. cit., s. 1028.

34 D. Danecka, op. cit., s. 344.

35 W. Radecki, Delikty..., s. 21.
} 
administracyjnej od odpowiedzialności karnej i odpowiedzialności za wykroczenie nie jest możliwe. Odpowiedzialność administracyjna nieustannie ewoluuje, stosowanie zaś administracyjnych kar pieniężnych coraz bardziej podobne jest do form przewidzianych $\mathrm{w}$ prawie karnym ${ }^{36}$. W związku $\mathrm{z}$ tym koncepcji zamiany odpowiedzialności za wykroczenie w odpowiedzialność administracyjną nie można utożsamiać $\mathrm{z}$ całkowitym przekształceniem jej charakteru prawnego. Zarówno bowiem kary przewidziane za wykroczenia, jak i administracyjne kary pieniężne są sankcjami pełniącymi funkcje represyjne oraz prewencyjne. Ich charaktery prawne oraz funkcje zatem wzajemnie się przenikają. Niemniej jednak w wypadku administracyjnych kar pieniężnych głównym celem jest ochrona wartości wynikających z norm prawa administracyjnego, toteż ich funkcja prewencyjna jest pierwszoplanowa ${ }^{37}$. Na gruncie prawa wykroczeń z kolei środki penalne noszą cechy kary kryminalnej. Ich istotą, a zatem czynnikiem decydującym o abstrakcyjnym kształcie i treści w danym czasie, jest represja. Aczkolwiek nieco inny charakter ma grzywna nakładana w trybie postępowania mandatowego, która wykazuje cechy środka karno-administracyjnego. Na gruncie postępowania mandatowego nie jest możliwa realizacja wszystkich zasad i dyrektyw wymiaru kary sformułowanych odnośnie do kar ściśle kryminalnych. Dodatkowo grzywnę w tym trybie wymierzają organy administracji ${ }^{38}$.

Współczesny dyskurs dotyczący ogólnych zagadnień prawa wykroczeń, w tym głównie problemu kryteriów wyodrębnienia tej części systemu prawa, istoty czynu zabronionego i powiązanej z nim odpowiedzialności, funkcji tejże odpowiedzialności oraz stosowanych w jej ramach sankcji, zdominowany jest ujmowaniem tej problematyki w perspektywie karnistycznej. Nie sposób jednak pominąć wpływów na tę dziedzinę także prawa administracyjnego ${ }^{39}$. W. Radecki wskazuje, że pojęcie wykroczenia wiąże się zarówno z administracją państwową, jak i ze zwalczaniem czynów godzących głównie w prawidłowość działania administracji za pomocą kar. W związku ze specyfiką prawa wykroczeń można je zaliczać albo do prawa administracyjnego, z uwagi na jego służebną rolę wobec administracji, albo do prawa karnego ze względu na posługiwanie się karą. Możliwe jest także rozwiązanie kompromisowe, umiejscowiające prawo wykroczeń po części w dziedzinie prawa administracyjnego i prawa karnego, albo akcentujące samodzielność prawa wykroczeń i jego związków z prawem administracyjnym i prawem karnym ${ }^{40}$. Obecnie odpowiedzialność za delikty administracyjne nie jest

36 D. Danecka, op. cit., s. 341.

37 Kodeks postepowania administracyjnego. Komentarz, red. R. Hausner, M. Wierzbowski, Warszawa 2019, art. 189b.

38 J. Jakubowska-Hara, [w:] Kodeks wykroczeń. Komentarz, red. P. Daniluk, Warszawa 2019, s. 130.

39 P. Kardas, M. Sławiński, Przenikanie odpowiedzialności wykroczeniowej i administracyjnej - problem podwójnego karania, [w:] Węzłowe problemy..., s. 22-23.

40 W. Radecki, [w:] M. Bojarski, W. Radecki, op. cit., s. 7. 
przyporządkowana do żadnej regulacji o ogólnym charakterze, a jej praktyczne znaczenie jest większe niż odpowiedzialności za wykroczenia ${ }^{41}$. Należy się zgodzić, że w stosunku do administracyjnych kar pieniężnych powinny być stosowane wszystkie gwarancje prawne przewidziane dla odpowiedzialności karnej sensu largo. Tym bardziej zatem niezbędne staje się precyzyjne i klarowne określenie zasad odpowiedzialności za wszystkie sankcje administracyjne ${ }^{42}$. W doktrynie nie milkną postulaty o całościowe uregulowanie odpowiedzialności za delikty administracyjne w odrębnym akcie prawnym.

\title{
THE CONCEPTION OF CONVERTING RESPONSIBILITY FOR PETTY OFFENCES INTO ADMINISTRATIVE RESPONSIBILITY
}

\author{
Summary
}

The article discusses an important issue placed at the intersection of petty offences law and administrative law. The legislator, by following the concept of conversion, transforms some of the petty offences into administrative delicts threatened within administrative financial penalties. The purpose of the article is to present the problems of conversion of petty offences into administrative delicts. The postulates for comprehensive regulation of administrative delicts in a separate legal act should be strongly emphasised.

Keywords: a petty offence, an administrative tort, administrative financial penalties, conversion, petty offences law

\section{BIBLIOGRAFIA}

Adamiak B., Borkowski J., Kodeks postepowania administracyjnego. Komentarz, Warszawa 2019. Bogucka M., Odpowiedzialność karna a odpowiedzialność administracyjna w kontekście kary pieniężnej w prawie farmaceutycznym, KKRS 2018, nr 2.

Czichy K., O niestosowaniu gwarancji karnych do administracyjnych kar pieniężnych, Prok. i Pr. 2017, $\mathrm{nr} 12$.

Danecka D., Konwersja odpowiedzialności karnej w administracyjna w prawie polskim, Warszawa 2018.

Jakubowska-Hara J., [w:] Kodeks wykroczeń. Komentarz, red. P. Daniluk, Warszawa 2019.

Kardas P., Sławiński M., Przenikanie odpowiedzialności wykroczeniowej i administracyjnej - problem podwójnego karania, [w:] Węzłowe problemy prawa wykroczeń - czy potrzebna jest reforma?, red. M. Kolendowska-Matejczuk, V. Vacher, Warszawa 2016.

Kodeks postępowania administracyjnego. Komentarz, red. R. Hausner, M. Wierzbowski, Warszawa 2019.

Radecki W., [w:] M. Bojarski, W. Radecki, Kodeks wykroczeń. Komentarz, Warszawa 2019.

41 W. Radecki, [w:] Reforma prawa..., s. 47.

${ }^{42} \mathrm{~K}$. Czichy, O niestosowaniu gwarancji karnych do administracyjnych kar pieniężnych, Prok. i Pr. 2017, nr 12, s. 103. 
Radecki W., [w:] Reforma prawa wykroczeń, red. P. Daniluk, t. 1, Warszawa 2019.

Radecki W., Delikty administracyjne w prawie czeskim po reformie prawa wykroczeń z polskiej perspektywy, Prok. i Pr. 2020, nr 1.

Rogalski M., Aksjologia administracyjnych kar pieniężnych, [w:] Aksjologia prawa administracyjnego, t. 1, red. J. Zimmermann, Warszawa 2017.

Sepioło-Jankowska I., Odpowiedzialność administracyjna jako odpowiedzialność alternatywna dla deliktów finansowych, Prok. i Pr. 2020, nr 1.

Stec M., Założenia aksjologiczne rzadowego procesu legislacyjnego i ich realizacja, [w:] Aksjologia prawa administracyjnego, t. 1, red. J. Zimmermann, Warszawa 2017.

Stefański R.A., Odpowiedzialność administracyjna czy karna sensu largo?, [w:] Węzłowe problemy prawa wykroczeń - czy potrzebna jest reforma?, red. M. Kolendowska-Matejczuk, V. Vacher, Warszawa 2016.

Szumiło-Kulczycka D., Prawo administracyjno-karne, Kraków 2004.

Wincenciak M., Aksjologia sankcji administracyjnej a przedawnienie jej wymierzania lub wykonania, [w:] Aksjologia prawa administracyjnego, t. 1, red. J. Zimmermann, Warszawa 2017.

Zawłocki R., Pojęcie i istota deliktu administracyjnego, MOP 2018, nr 1.

Zimmermann J., Aksjomaty prawa administracyjnego, Warszawa 2013.

Żołnierczyk E., Sankcja administracyjna - rozważania na temat administracyjnych kar pieniężnych wprowadzonych nowelizacja Kodeksu postepowania administracyjnego z 2017 r., [w:] Polski system ochrony praw człowieka 70 lat po proklamowaniu Powszechnej Deklaracji Praw Człowieka. Osiagnięcia - bariery - nowe wyzwania i rozwiązania, red. J. Jaskiernia, K. Spryszak, Toruń 2019. 